\title{
PROMISING METHODS FOR NONINVASIVE MEDICAL DIAGNOSIS BASED ON THE USE OF NANOPARTICLES: SURFACE-ENHANCED RAMAN SPECTROSCOPY IN THE STUDY OF CELLS, CELL ORGANELLES AND NEUROTRANSMITTER METABOLISM MARKERS
}

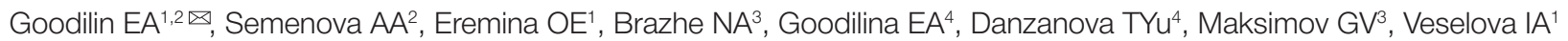 \\ ${ }^{1}$ Faculty of Chemistry, Lomonosov Moscow State University, Moscow \\ ${ }^{2}$ Faculty of Materials Science, Lomonosov Moscow State University, Moscow \\ ${ }^{3}$ Faculty of Biology, Lomonosov Moscow State University, Moscow \\ ${ }^{4}$ Blokhin Russian Cancer Research Center, Moscow
}

\begin{abstract}
Application of advances in nanomedicine and materials science to medical diagnostics is a promising area of research. Surface-enhanced Raman spectroscopy (SERS) is an innovative analytical method that exploits noble metal nanoparticles to noninvasively study cells, cell organelles and protein molecules. Below, we summarize the literature on the methods for early clinical diagnosis of some neurodegenerative and neuroendocrine diseases. We discuss the specifics, advantages and limitations of different diagnostic techniques based on the use of low- and high molecular weight biomarkers. We talk about the prospects of optical methods for rapid diagnosis of neurotransmitter metabolism disorders. Special attention is paid to new approaches to devising optical systems that expand the analytical potential of SERS, the tool that demonstrates remarkable sensitivity, selectivity and reproducibility of the results in determining target analytes in complex biological matrices.
\end{abstract}

Keywords: medical diagnostics, nanomaterials, noble metal nanoparticles, surface-enhanced Raman spectroscopy, mitochondria, erythrocytes, neurotransmitter markers, nanomedicine

Funding: this work was supported by the Russian Science Foundation (Grant 14-13-00871).

Acknowledgments: the authors wish to thank Professor Chekhonin VP, who graciously agreed to collaborate on this project, Nickelsparg E. for her assistance in preparing the figures for the manuscript, and Professor Sinukova GT for the fruitful discussion of contrast-enhanced ultrasound diagnostics.

$\triangle$ Correspondence should be addressed: Eugene A. Goodilin Leninskie gory 1, bl. 3, Moscow, 119992; goodilin@yandex.ru

Received: 20.07.2018 Accepted: 19.08.2018

DOI: $10.24075 /$ brsmu.2018.077

\section{ПЕРСПЕКТИВНЫЕ МЕТОДЫ НЕИНВАЗИВНОЙ МЕДИЦИНСКОЙ ДИАГНОСТИКИ С ИСПОЛЬЗОВАНИЕМ НАНОМАТЕРИАЛОВ: СПЕКТРОСКОПИЯ ГИГАНТСКОГО КОМБИНАЦИОННОГО РАССЕЯНИЯ В ИССЛЕДОВАНИИ КЛЕТОК, КЛЕТОЧНЫХ ОРГАНЕЛЛ, МАРКЕРОВ НЕЙРОМЕДИАТОРНОГО ОБМЕНА}
Е. А. Гудилин ${ }^{1,2}$ И. А. Веселова

\footnotetext{
Химический факультет, Московский государственный университет имени М. В. Ломоносова, Москва

2 Факультет наук о материалах, Московский государственный университет имени М. В. Ломоносова, Москва

Б Биологический факультет, Московский государственный университет имени М.В.Ломоносова, Москва

${ }^{4}$ Национальный медицинский исследовательский центр онкологии имени Н. Н. Блохина, Москва
}

\begin{abstract}
Использование достижений наномедицины и материаловедения в диагностике заболеваний является перспективным направлением научных исследований. Спектроскопия гигантского комбинационного рассеяния (ГКР) инновационный метод анализа, связанный с применением наноматериалов на основе благородных металлов для неинвазивного исследования клеток, клеточных органелл, белковых молекул. В работе обобщены литературные данные по методам ранней клинической диагностики ряда нейродегенеративных и нейроэндокринных заболеваний. Обсуждены особенности, достоинства и ограничения различных методов диагностики по низкомолекулярным и высокомолекулярным маркерам указанных заболеваний. Продемонстрированы перспективы применения оптических методов для экспресс-диагностики нарушений нейромедиаторного обмена. Особое внимание уделено новым подходам при создании универсальных оптических индикаторных систем, расширяющих аналитические возможности спектроскопии ГКР, обладающей уникально высокой чувствительностью, селективностью и воспроизводимостью результатов анализа при определении целевых аналитов в биологических матрицах сложного состава.
\end{abstract}

Ключевые слова: медицинская диагностика, наноматериалы, наночастицы благородных металлов, гигантское комбинационное рассеяние, митохондрии, эритроциты, маркеры нейромедиаторного обмена, наномедицина

Финансирование: работа поддержана Российским научным фондом (грант 14-13-00871).

Благодарности: авторы благодарны академику В. П. Чехонину за возможность творческого сотрудничества и Э. Никельшпарг за помощь в подготовке иллюстраций к обзору, а также профессору Г. Т. Синюковой за плодотворное обсуждение результатов ультразвуковой диагностики с использованием контрастных агентов.

$\checkmark$ Для корреспонденции: Евгений Алексеевич Гудилин

Ленинские горы, д. 1, стр. 3, г. Москва, 119992; goodilin@yandex.ru

Статья получена: 20.07.2018 Статья принята к печати: 19.08.2018

DOI: $10.24075 /$ vrgmu.2018.077 
In the past 10-15 years, the evolution of nanomedicine and materials science made possible by the findings of interdisciplinary studies at the interface of chemistry, physics and biology has been driven by the challenges of medical diagnosis [1-3]. Hopes are high for research into targeted drug delivery, theranostics, discovery of therapeutic nanoparticles and diagnostic nanomaterials, including contrasting agents for scintigraphy, CT, MRI and ultrasonography (Fig. 1). Some of them have already been launched onto the market and set a new standard for medical imaging. Yet, there is a lot to be done, including creation of next-generation biosensing systems $[1,2,4-11]$.

Surface-enhanced Raman scattering (or spectroscopy, SERS) holds an important place among actively evolving noninvasive diagnostic techniques. It is an optical analytical modality with record-breaking sensitivity that can be applied to the study of nature objects; it is also a unique approach to rapid detection assays [12-15]. Because of its underlying physical principles, SERS urges development of novel silverand gold-derived nanomaterials with programmable properties. Noble metal nanoparticles are highly inert, both chemically and biologically, and allow effective control over surface plasmon resonance and distribution of externally induced local electromagnetic fields (Fig. 2). Among prioritized applications of SERS are nondestructive analysis of biological objects, cells or cell fragments [16-22], including red blood cells [16, 17, 23-25], bacteria [26-28], viruses [29, 30], stem cells [31, 32], human tissue cells in general [33], and cancer cells in particular[34-37]; quality control in the pharmaceutical and food industries [38, 39]; detection and quantification of proteins, peptides, and DNA molecules [9, 15, 19-21], low molecular weight biomarkers of pathological conditions, and toxic agents [9-11, 36, 40-42]. Most research works on SERS conducted recently sought the way to introduce SERS into routine practice, proving that SERS has a big future in biological and medical diagnostics.

SERS has been around since 1974 [43]. However, it was not until 2010-2012 that it gradually came to be extensively used for noninvasive analysis of living cells and cell organelles, which was dictated by the need for novel nanomaterials and instrumental approaches [9, 13, 16-20]. SERS can be successfully combined with in vivo bioimaging [44] or microfluidic systems [45] that significantly expand the scope of its application. SERS has remarkable sensitivity crucial for the detection and quantification of trace amounts of analytes, down to the level of single molecules. Much anticipated is the adoption of SERS for multiplex detection of analytes in complex matrices. Indeed, SERS has the necessary potential because Raman spectra are determined by the molecular composition of an analyte. It means that SERS is capable of identifying analytes in complex mixtures based on their molecular fingerprints and determining molecular conformations.

Although SERS demonstrates exceptional sensitivity in detecting the presence of ultralow concentrations (from nM to $\mathrm{fM}$ ) of analytes in complex matrices, it may not be that successful at analyte quantitation. SERS is a spatially localized analytical technique: signal enhancement occurs at distances less than 10-15 nm from a nanostructured surface and largely depends on its texture, condition, size, anisotropy, specifics of analyte sorption by nanoparticles, their mutual orientation and tendency to aggregate [9]. Therefore, the functional properties
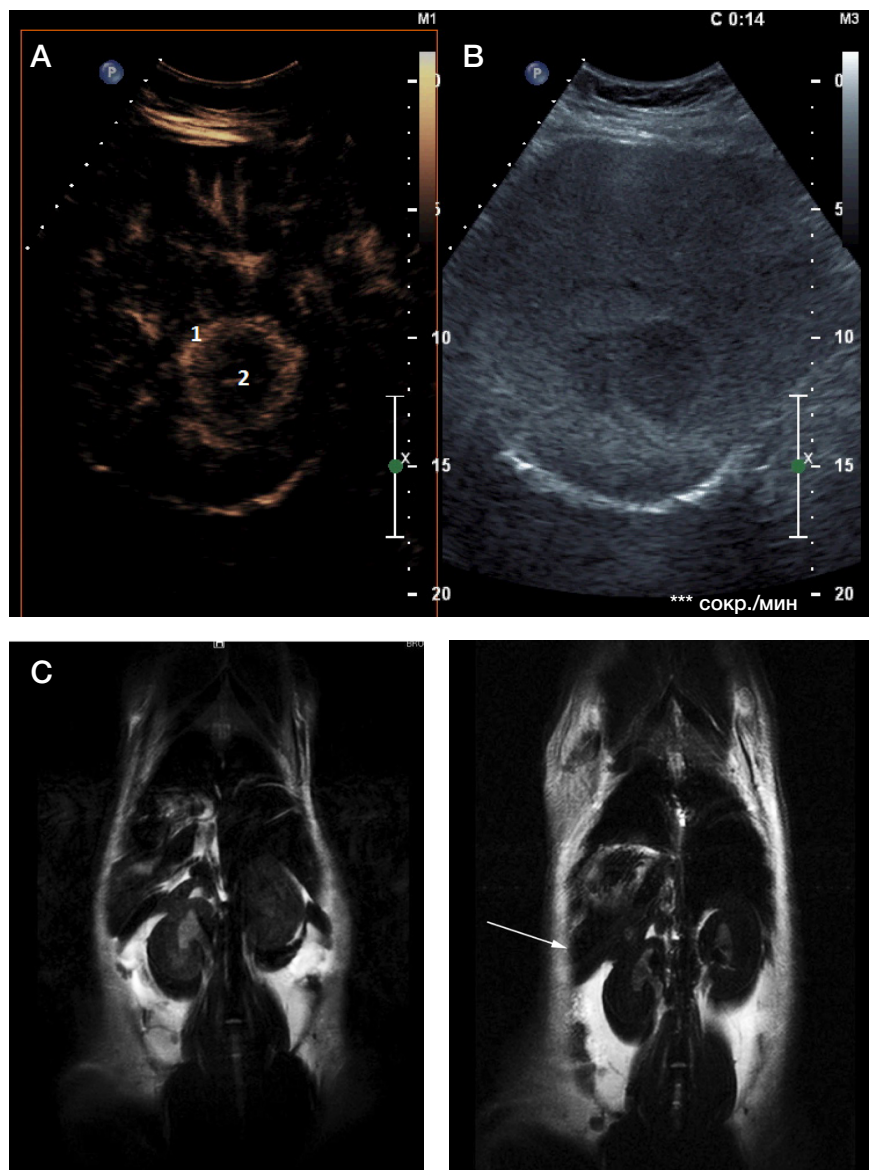

Fig. 1. Contrasting agents in medical imaging (photos are provided by the authors of this article). A, B. A contrast-enhanced ultrasound scan of the liver with a metastatic lesion: $\mathbf{A}$ - the arterial phase (14 seconds after the injection of SonoVue), 1 - peripheral enhancement; 2 - no enhancement in the central region; B - the gray-scale B-mode. C. A contrast-enhanced MR image of a rat's spleen (enhancement with iron oxide PEG-shell nanoparticles) 
of a synthetic nanomaterial are determined by its morphology, microstructure and a wide range of physical and chemical properties.

SERS modifications tailored to suit specific needs can be further refined to improve the reproducibility, sensitivity and selectivity of the method and solve the problem of quantitative analysis. Here, an important contribution has been made by the study of hot spots - areas of a very strong electromagnetic field in the crevices between nanoparticles [9]. Hot spots play a significant role in the SERS effect because $10^{7}-10^{8}$-fold signal enhancement is registered in these particular regions.

Currently existing approaches to chemical synthesis are capable of producing high yields of silver nanoparticles (AgNP) different in their size and shape (spheres, tetrahedra, decahedra, triangular and hexagonal plates, discs, rods, threads, more complex shapes) [9, 46-51]. Physical methods of AgNP synthesis include laser ablation, thermal evaporation, arc discharge, electron-beam deposition, ion-beam sputtering, ion implantation, and different types of radiation. Interestingly, AgNP can be synthesized using naturally occurring compounds [5255]. Planar structures are traditionally obtained using lithography, electrochemical approaches, vapor phase synthesis, chemical precipitation, Langmuir-Blodgett films, copolymer micelles, inoculation of microsphere surface functionalized with amino or thiol groups with preformed nanoparticles, and spraying of nanoparticles onto scaffolds, such as cellulose carriers, replica surfaces, etc. [9, 11, 13, 16, 17, 25]. The listed trends in SERS research aimed at designing reliable SERS-active surfaces, sensors and analytical techniques are paving the way for SERS applications in biomedical diagnostics.

\section{Noninvasive diagnostic modalities for biological objects}

Among the most interesting SERS applications that are being explored at the moment is early detection of trace amounts of bioactive molecules in physiological solutions (blood, saliva and cerebrospinal fluid). One of the recent advances in this field is a method that utilizes a combination of SERS and immunoassays exploiting the principle of specific antigen binding by a complementary antibody [56]. The use of SERS labels in combination with composite materials based on microbeads and metal nanoparticles facilitates development of targeted immunoassays for highly sensitive detection of biomolecules [56-58]. Another important field of SERS application is biosensors for analyte quantitation that rely on plasmon particles with chemically modified surfaces. As a rule, such modifications are achieved by coating the surface with a monolayer of functional thiol groups and are necessary for the subsequent sorption of analytes and preconcentration [59]. This approach enables real-time measurement of glucose levels (> $25 \mathrm{Mm}$, which is close to typical glucose concentrations occurring in some physiological fluids) in the presence of model plasma proteins (bovine serum albumin) or following a long (up to 3 days) contact of a sensor with electrolytes taken at physiological concentrations. When subcutaneously implanted in experimental animals, SERS-based sensors stably demonstrate high accuracy and reproducibility of the results over the course of at least 2 weeks; this suggests that such sensors have a good potential to be used for in situ monitoring of biological processes in living organisms [59]. The use of nanostructured surfaces for the study of biological objects may have an advantage over other methods because nanomaterials ensure the reproducibility of signal enhancment and allow integration of SERS-active substrates into a lab-on-a-chip or a microfluidic device. No matter what nanostructures are used to study biological objects, there are a few requirements they must satisfy, including zero toxicity against cells, chemical and morpholoigcal stability in biological fluids and solutions, an ability to reliably enhance the SERS signal as much as possible, zero interference with biological processes inside the cell and confirmations of molecules a sensor has a direct contact with.

Surface-enhanced Raman spectroscopy is also employed in cancer research $[60,61]$. SERS-based sensors are capable of measuring intracellular redox potential. One of them was designed to study oxidative stress in cells; the sensor is composed of gold nanobeads enriched in quinones that act as redox-sensitive molecules and operates in a range between -400 and $+100 \mathrm{mV}$ exceeding the capacity of fluorescent probes [62]. Another example of a SERS-based sensor is a highly selective hybrid nanosensor made of silver nanoparticles coated with cytochrome c. It was designed to measure concentrations of a superoxide anion radical inside the cell and has a detection threshold of $10 \mathrm{nM}$ [63]. Its underlying principle is as follows: when an electron is transferred from a superoxide anion radical to cytochrome $c$, the band representing oxidized cytochrome $c$ in SERS spectra undergoes a shift to the position typical of reduced cytochrome $c$.

Of interest is the approach based on the use of nanostructures functionalized with molecules that do not produce an intense SERS spectrum but can specifically bind to a biological object whose SERS spectrum is recorded instead. This approach can be exemplified by a highly sensitive sensor that detects the presence of bacteria in blood [64]. The authors of the invention coated gold and silver-gold nanostructured composites with vancomycin that can specifically bind to gram-positive bacteria. Vancomycin causes deformation of the bacterial cell wall promoting aggregation of nanoparticles and thereby enhancing the SERS signal. Such nanostructured substrates can be used in multifunctional biochips: vancomycin can be replaced with other glycopeptides, which will expand the range of microorganisms and viruses the system can detect. Another team of researchers conducted a number of experiments involving the use of glass microcapillaries coated with gold nanoparticles that was introduced into the cell [65]. Depending on where the capillary was located inside the cell, signal enhancement occurred in the nucleus or cytoplasm; the emitted spectra reflected the functional state of the cell. Another novel method is based on the use of surfaces coated with gold nanoparticles and serves to detect a secondary messenger an intracellular molecule released in response to stimulation of cell receptors and activation of primary effector proteins in $\mathrm{Ca}^{2+}$-signaling of NADP [66]. A new approach based on the use of gold nanomaterials has been devised to perform highly sensitive detection of conformational changes in nucleic acids and proteins, as well as cell visualization in vivo [9, 19, 20]. Another team of researchers suggest that functionalized gold nanoparticles can be used to discriminate between different types of lymphocytes and detect leukemic cells [67].

One of the most important areas of SERS research covers the possibility of highly selective enhancement of the SERS signal from those intracellular molecules whose conformation and properties are indicators of their functional state and the state of the entire cell in general and individual organelles in particular. Among the biomolecules that can be conveniently used in basic and applied research are heme proteins: hemoglobin $(\mathrm{Hb})$ and cytochromes. It is known that heme porphyrins and heme proteins produce a strong and highly specific SERS effect [68] determined by the redox state of the iron atom, heme conformation and conformation of its protein microenvironment. This fact makes it possible 

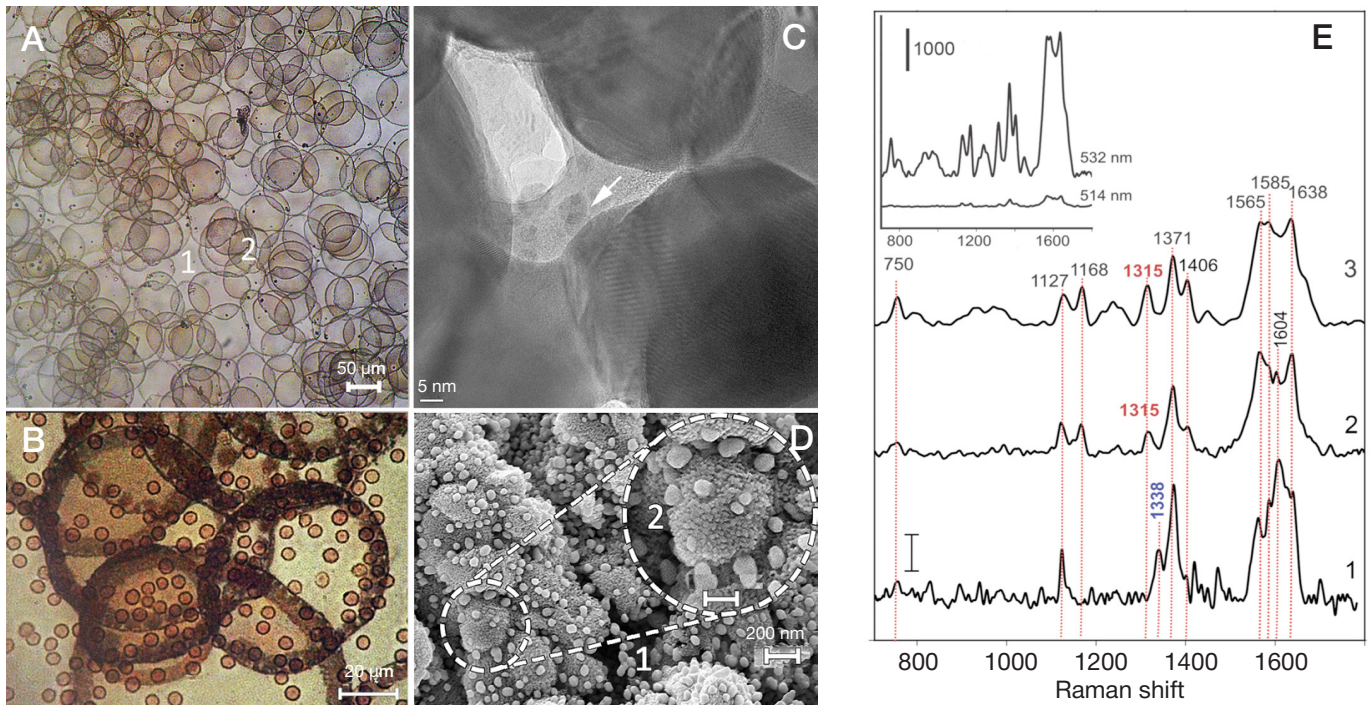

Fig. 2. The Ag nanostructured surface for SERS-based analysis. A. An optical microphotograph of silver rings. B. Living red blood cells on the nanostructured surface. C. Nanostructured elements of the surface (Ag nanoparticles in the substrate channels, TEM). D. "Sesame seeds" on the nanostructured substrate (SEM). E. SERS spectra of red blood cells (1) and mitochondria (2 and 3) on the Ag@SiO nanocomposite at laser excitation wavelength of $532 \mathrm{~nm}(1 \mathrm{and} 3)$ and 514 nm (2). For convenience, the spectra were normalized to their total intensity. Figures above the spectra indicate the position of peak maxima. The inset plot shows unnormalized SERS spectra of mitochondria on the Ag@SiO, nanocomposite at laser excitation wavelength of 514 and $532 \mathrm{~nm}$

to study mitochondrial cytochromes in cells or organs [9] and hemoglobin in whole blood, isolated red blood cells or vascular erythrocytes in vivo. There are, however, a few limitations to the use of traditional spectroscopy in the study of heme porphyrins. For example, oxidized cytochromes produce weak and therefore undetectable scattering effects. When studying red blood cells, one should bear in mind that SERS spectra can be obtained only from cytoplasmic $\mathrm{Hb}\left(\mathrm{Hb}_{\mathrm{cyy}}\right)$, which constitutes the largest proportion of total $\mathrm{Hb}$, but not from membrane-bound $\mathrm{Hb}\left(\mathrm{Hb}_{\mathrm{mb}}\right)$ whose conformation can change in patients with blood diseases, hereditary or endocrine disorders (thalassemia, hemoglobinopathy, etc.) [69], intoxication, or under extreme conditions [70]. In those cases, signal enhancement is caused by $\mathrm{Hb}_{\mathrm{mb}}$ located in close proximity to silver nanostructures. Thus, the use of SERS-active nanostructures is indispensable in the study of heme proteins and can serve as a basis for rapid noninvasive medical testing and screening.

The authors of the present article have proposed a nove methodological approach, developed and synthesized nanostructured materials with planar architecture and $\mathrm{Ag}_{2} \mathrm{SiO}_{2}$ nanocomposites, which allowed them to attain highly reproducible and selective enhancement of the SERS signal from cytochrome $c$ of a respiratory chain (electron transport chain, ETC) of intact, normally functioning mitochondria (Fig. 2D). Using the original method, the authors were able to study conformational changes and redox properties of cytochrome $c$ in intact, normally functioning mitochondria under the conditions of modulated ETC activity [9, 18]. The study also demonstrated changes in the redox state and conformation of cytochrome $c$ heme molecules induced by the inhibition of ATP synthase and introduction of protonophore FCCP, which causes the uncoupling of electron transport and ATP synthesis. The SERS-based analyis involving the use of planar silver plasmon structures allowed the authors to estimate the changes in the relative concentrations of reduced cytochrome $c$ in mitochondria and the conformational mobility of cytochrome $c$ heme both inside mitochondria and in its isolated state (Fig. 2D). Using intact mitochondria, the authors demonstrated that the FCCP protonophore capable of uncoupling electron transport and ATP synthesis and oligomycin, which inhibits the ATP synthase, produce opposite effects on relative cytochrome $C$ concentrations and the mobility of methine bridges in heme molecules [18], whereas mutant cytochrome $c$ whose heme molecules exhibit increased rigidity enjoys lower conformational mobility and functional activity of heme. It is hypothesized that conformational changes that cytochrome $c$ undergoes might be employed by mitochondria to vary the rate of electron acceptance from ETC complex III and electron transfer to complex IV. The proposed methodological approach is a promising tool for further study of ETC in intact mitochondria. Application of SERS-active nanostructures to biomedicine necessitates discovery of novel analytical methods for integrating nanostructures into a lab-on-a-chip.

\section{Rapid diagnosis of neurotransmission disorders}

Neurotransmission is a cornerstone of neural mediation in both peripheral and central nervous systems [71]. Among the key neurotransmitters are 3 catecholamines (CA): dopamine, adrenaline (epinephrine) and noradrenaline (norepinephrine), and their metabolites, including vanillylmandelic, homovanillic and 5-hydroxyindoleacet acids, metanephrine and normetanephrine. CA metabolism is a crucial regulator of mental and physical activities: through dopaminergic and adrenergic receptors, CA control stress response, psychomotor activity, emotions, learning, sleep, and memory [72]. Because $\mathrm{CA}$ are involved in the pathogenesis of many diseases, they are extensively used in pharmacology [73]. Neurotransmission disorders are divided into two major groups: neurodegenerative diseases accompanied by the progressive loss of neural cells and the decline in CA levels (and, naturally, the levels of their metabolites) and neuroendocrine diseases characterized by increased CA synthesis induced by organic pathology or genetic defects of the hypothalamus. Among the most important neurodegenerative disorders are Alzheimer's and Parkinson's diseases. The most common neuroendocrine catecholamineproducing tumors are pheochromocytoma, paraganglioma, and neuroblastoma.

Neuroendocrine tumors pose a serious diagnostic challenge: the malignancy is often diagnosed retrospectively, in its advanced metastatic stages or during a relapse episode. In Russia, over 90\% of neurodegenerative disorders are 
misdiagnosed because their symptoms are confused with the signs of aging. Many neurodegenerative disorders are alike in their clinical manifestations, which also complicates the diagnosis [74]. The most dangerous neuroendocrine diseases accompanied by increased CA levels are pheochromocytoma and paraganglioma - benign and malignant catecholamineproducing tumors, respectively. They arise from chromaffin cells of the sympathoadrenal system and in $90 \%$ of cases occur in the adrenal medulla [75]. Carcinoid tumors constitute less than $1 \%$ of all malignancies and are formed by the cells of the diffuse neuroendocrine system; these cells are derived from the neural crest during fetal development and later migrate to other organs [76]. Another malignant tumor, neuroblastoma produces multiple metastases. The majority of these tumors occur in the retroperitoneal space, most commonly in the suprarenal glands, mediastinum or neck [77].

Dopamine, noradrenaline and their metabolites can be used as molecular markers to facilitate the diagnosis of Alzheimer's and Parkinson's diseases: the onset of the disease can be inferred from the decline in their concentrations in biological fluids. It has been shown that as the symptoms of Parkinson's progress, the ratio of dopamine to dioxy phenylacetic acid (DOPAA) in urine decreases and production of dopamine and dioxyphenylalanine (DOPA) declines. The patient develops pronounced deficit of catecholamine neurotransmitters (dopamine, noradrenaline and serotonin) in the early stages of the disease, accompanied by dopamine catabolism which results from increased oxidative deamination of this neurotransmitter. However, early manifestations of Parkinson's occur in the backdrop of increased dopamine turnover compensating for neural loss. As cell degeneration progresses, DOPA levels dwindle, as does the dopamine/DOPAA ratio, indicating neurotransmission pathology and the lack of monoamine oxidase activity, which suggests depletion of resources for CA synthesis. Thus, decreasing concentrations of CA in Parkinson's and their relatively simple molecular structure make CA promising biological markers of this disease.

In healthy individuals CA levels are very low (about $1 \mathrm{nM}$ ), shrinking further in pathology (Alzheimer's and Parkinson's). In blood, CA are quickly oxidized by platelet monoamine oxidases. Therefore, CA tests should take no longer than 15 to 30 minutes. This poses a certain difficulty and necessitates development of rapid specific and sensitive assays for determining CA and their metabolites in biological fluids.

At present, early diagnosis of neurodegenerative disorders is facilitated by a variety of neuroimaging modalities, including MRI, CT, PET (positron emission tomography), SPECT (single-photon emission computed tomography), ${ }^{1} \mathrm{H}-\mathrm{MRS}$ (proton magnetic resonance spectroscopy), EEG (electroencephalography), etc. [10, 11]. In recent years, PET and SPECT have been adopted to clinical practice to aid the diagnosis of Alzheimer's and Parkinson's diseases. However, the availability of these radionuclide-based imaging techniques is largely determined by an arsenal of available labeled compounds referred to as radiopharmaceuticals (RP) that are administered to the patient before the scan. As a rule, RP used in PET are based on bioactive short- $\left({ }^{18} \mathrm{~F}\right)$ and ultrashort-lived $\left({ }^{11} \mathrm{C},{ }^{13} \mathrm{~N},{ }^{15} \mathrm{O}\right)$ positron-emitting radionuclides [10]. SPECT, another imaging modality, is instrumental in assessing the functional state of brain regions. SPECT can help to differentiate between neurodegenerative diseases that have similar clinical manifestations but affect different parts of the brain. But although neuroimaging is an accurate diagnostic tool for early diagnosis of neurodegenerative and neuroendocrine conditions, it has no prognostic value in patients with neurotransmission disorders. Besides, neuroimaging equipment and consumables are expensive, and a patient may not have clear indications for the procedure. In spite of high prevalence of neurotransmission disorders, neuroimaging is often available only to the residents of big cities. Therefore, novel approaches are needed to create a rapid, cheap, simple and sensitive system for multiplex detection of biomarkers associated with neurological pathology.

Traditional immunoassays are a simple and available diagnostic tool for suspected Alzheimer's or Parkinson's. Neurotransmission biomarkers determined by such assays comprise a number of high molecular weight compounds, such as $\beta$-amyloid, the tau protein, and the phosphorylated tau protein, in the first place. Patients with Parkinson's disease accumulate synuclein, whereas patients with Alzheimer's develop senile plagues (protein deposits of $\beta$-amyloid). A lot of effort has been channeled into the development of novel techniques for $\beta$-amyloid determination in recent years. Distribution of $\beta$-amyloid in the body can be studied by radioisotope-based instrumental modalities, as well as by immunoassays of cerebrospinal fluid $[10,11]$. The procedure of sample preparation for such assays, however, is too complicated and time-consuming. On the whole, even though immunoassays for measuring concentrations of biomarkers associated with neurodegenerative disorders hold certain promise, they have limitations related to the object of analysis itself and the structure of diagnostic molecules. Besides, concentrations of protein biomarkers can vary depending on the age and sex of a patient [10] causing the assay to yield false results. Neuroendocrine diseases have their own protein biomarkers. For example, chromogranin A (CgA) present in chromaffin granules of neuroendocrine cells is a biomarker of pheochromocytoma, paraganglioma, neuroblastoma, and carcinoid tumors $[10,11]$. However, this method cannot reliably discriminate between the listed pathologies. Therefore, patients with suspected neuroblastoma are tested not only for the traditional biochemical markers, but also for neuron-specific enolase, ferritin, lactate dehydrogenase, and $\gamma$-glutamyl transferase $[10,11]$. High on the agenda are the search for and the study of nonprotein biomarkers, such as CA and their metabolites, as well as development of simple selective and highly sensitive methods for measuring their concentrations that will ensure accurate and reliable diagnosis early in pathology.

The process of neurotransmission involves inactivation of CA and their metabolism. CA are methoxylated in the presence of catechol-o-methyl transferase; the reaction produces metanephrine and normetanephrine. Besides, CA undergo oxidative deamination in the presence of monoamine oxidase; the end products of this reaction are vanillylmandelic and homovanillic acids $[10,11]$. Because the levels of CA and their metabolites are different in health and pathology, these catecholamines can be used as diagnostic markers in basic research and clinical tests. Among the methods aiding neuroendocrine or neurodegenerative diagnosis based on blood or urine levels of CA or their metabolites, chromatography combined with electrochemical detection or mass spectrometry (MS) is the most popular [11]. In spite of high selectivity, sensitivity and availability of electrochemical detectors, its results are poorly reproducible, it is sensitive to fluctuations of the mobile phase flow rate, is not free of electrode contamination, and imposes strict requirements on the origin of the mobile phase. High-performance liquid chromatography with electrochemical detection (HPLC-ED) suffers high levels of background noise (in comparison with a useful signal), does not always have sufficient sensitivity and demonstrates low separation efficacy. HPLC-MS is significantly more sensitive 
to CA and their metabolites but at the same time insufficiently rapid and has a few limitations related to the elution of certain compounds in dead time, high levels of background noise and difficulties with peak resolution [11]. In spite of the vast body of accumulated knowledge and the extensive arsenal of methods for measuring CA in blood plasma and urine, poor reproducibility and resolution coupled with time required for the procedure produce a whole lot of diagnostic errors leading to ineffective treatment. The solution to this problem may lie in the development of electrochemical sensors [78]. In the majority of such sensors, indicator electrodes are functionalized with pre-synthesized compounds with a certain structure ensuring selective detection of CA. These compounds comprise DNA fingerprints, polymers, synthetic receptors, nanotubes and nanocores modified with organic molecules (polyethyleneimine, cyclodextrin, metal complexes) [79-81]. Electrochemical methods for CAVA metabolite determination have average sensitivity in the range between 0.01 and $1 \mu \mathrm{M}$. Unfortunately, the majority of electrochemical analytical methods cannot be multiplexed, which limits their application in clinical practice.

An alternative to the methods described above is spectroscopy, its primary advantages being the rate of analysis, simplicity, low costs, and in some cases higher sensitivity, as compared to its electrochemical or chromatography-based counterparts. Fluorescence-based modalities capable of detecting CA or their metabolites also hold some promise as diagnostic techniques. In the presence of enzymes, such as peroxidase [82], CA is oxidized by hydrogen peroxide; the end product of their oxidation is a compound capable of quenching fluorescence of water-soluble synthetic poly(2,5bis(3-sulfonatopropoxy)-1,4-phenylene, disodium salt-alt1,4-phenylene). The method exhibits low sensitivity towards individual CA types (about $0.1 \mu \mathrm{M}$ ), but can be multiplexed to selectively detect catecholamines over other molecules [83]. There are detection methods that utilize nanoparticles, including $\mathrm{F}_{\mathrm{e}} 3 \mathrm{O}_{4}$-based ones. These nanoparticles are used instead of horse radish peroxidase. The principle underlying this approach exploits the inhibition of Amplex UltraRed reagent (peroxidase substrate) oxidation by CA in the presence of hydrogen peroxide and $\mathrm{Fe}_{3} \mathrm{O}_{4}$ nanoparticles. The oxidized Amplex UltraRed emits an intense fluorescence signal with $587 \mathrm{~nm}$ wavelength at 567 $\mathrm{nm}$ excitation. CA covalently binds to the surface of iron oxide (III) nanoparticles and quenches fluorescence of the oxidized Amplex UltraRed. Although the sensitivity of the method is high (detection threshold of $3 \mathrm{nM}$ ), it can only selectively distinguish between catecholamines and other molecules but cannot be multiplexed [84]. Unfortunately, the sensitivity of the majority of similar methods is insufficient to allow quantitation of nanomolar concentrations of catecholamine, which limits the application of such biosensing systems to the analysis of biological objects $[10,11]$

SERS-based methods are more or less free of the major drawbacks associated with other analytical modalities employed for the detection of CA and their metabolites, such as low sensitivity and low rate of analysis. Unoptimized SERSbased methods can detect neurotransmitters at concentrations ranging from 0.1 to $0.5 \mathrm{M}$ [85], which obviously does not satisfy the requirements set for the analysis of biological fluids. A solution can be offered by highly sensitive and selective optical biosensing SERS-based systems, in which enhancement of the SERS signal is achieved through the effect of plasmon resonance occurring on a nanostructured surface of a noble metal, as described above. In such systems, specificity is ensured by capturing SERS signals with 1,500-650 $\mathrm{cm}^{-1}$ wavelength that provide valuable information about individual components of complex matrices. SERS is very sensitive even to minor changes in the structure and orientation of molecules. Considering its characteristics listed above and a weak SERS signal of water, SERS seems to be a promising analytical method with very little sample preparation that can be applied to complex matrices. Importantly, Raman spectroscopy ensures signal enhancement at a broad range of excitation frequencies, which allows selecting an excitation source that has minimal background autofluorescence and causes no damage to the sample. Nevertheless, today SERS is only making its first steps into clinical practice as a tool for the detection of neurotransmitters [9-11, 86]. Recently, SERS has been shown to be a feasible method for dopamine detection at concentrations between 1 and $10 \mathrm{mM}[87,88]$. Some authors have attained better sensitivity of 0.01-0.1 fM. SERS-based methods have demonstrated selectivity towards dopamine in the presence of ascorbic acid, glucose, L-cysteine, tyrosine, catechol, phenylethylamine, and serum albumin [89]. SERS can be easily combined with other modalities and improve their results. For example, selectivity exhibited by electrochemical methods for the detection of neurotransmitters in biological fluids is limited in the presence of ascorbic acid whose redox potential almost coincides with dopamine potential [90]. Using colloidal silver solutions, researchers were able to achieve a lower detection threshold of $5 \mathrm{nM}$ [91]. Other authors report formation of complexes accompanied by charge transfer that can help to attain a stable and intense SERS signal [92, 93]. There is no doubt that the approaches discussed in this article can be optimized further to reach pico- and femtomolar detection thresholds, promoting the use of SERS in biomedical diagnostics.

\section{CONCLUSIONS}

SERS has a very good potential as a biomedical analytical modality that can be applied to complex multicomponent matrices. It combines high sensitivity and high selectivity and requires little sample preparation. It also breaks ground for novel noninvasive multiplex detection of analytes in biological matrices. Further evolution of SERS depends on a number of factors. Those include research into SERS-active nanostructures focusing on their application in the clinical setting and comprehensive investigation of properties exhibited by such nanostructures in biological fluids and in contact with cells. Development of analytical methods with little sample preparation for simple, sensitive and selective multiplex detection of neurotransmitters, their metabolites or other biological markers in living cells or cell organelles holds promise for early diagnosis of various pathologies. The authors believe that optical systems for multiplex detection of pathology-associated biomarkers in biological fluids and cells constitute one of the most promising areas of research in clinical diagnostics and can significantly improve diagnostic accuracy. 
1. Semkina A, Abakumov M, Grinenko N, Abakumov A, Skorikov A Mironova E et al. Core-shell-corona doxorubicin-loaded superparamagnetic $\mathrm{Fe} 3 \mathrm{O} 4$ nanoparticles for cancer theranostics. Colloids Surf B Biointerfaces. 2015; (136): 1073-80.

2. Chekhonin VP, Baklaushev VP, Yusubalieva GM, Belorusova AE, Gulyaev MV, Tsitrin EB et al. Targeted delivery of liposomal nanocontainers to the peritumoral zone of glioma by means of monoclonal antibodies against GFAP and the extracellular loop of Cx43 Nanomedicine. 2012; 8 (1): 63-70.

3. Nukolova NV, Aleksashkin AD, Abakumova TO, Morozova AY, Gubskiy IL, Kirzhanova EA et al. Multilayer polyion complex nanoformulations of superoxide dismutase 1 for acute spinal cord injury. J Control Release. 2018; (270): 226-36.

4. Kovaleva EV, Sinyukova GT, Danzanova TY, Lepedatu PI, Gidulina EA, Vozmozhnosti UZI s primeneniyem contrastnogo usileniya $v$ diagnostike metastazov $v$ pecheni $u$ bolnih kolorectalnim rakom. Koloproktologiya. 2018; 1 (63): 36-42.

5. Bednikov SN, Sholokhov VN, Sinyukova GT, Goodilina EA, Abgaryan MG, Kalinin AE i dr. Differentsialnaya diagnostika ochagovih giperekhogennih orazovaniy v pecheni. Koloproktologiya. 2017; 2 (60): 19-25.

6. Nirmala D. Review: Medical image contrast enhancement techniques, Research Journal of Pharmaceutical Biological and Chemical Sciences. 2015; 6 (3): 321-9

7. Chen F, Hableel G, Zhao ER, Jokerst JV. Multifunctional nanomedicine with silica: Role of silica in nanoparticles for theranostic, imaging and drug monitoring. J Colloid and Interface Science. 2018; (521): 261-79.

8. Balthazar P, Shinagare AB, Tirumani SH, Jagannathan JP, Ramaiya NH, Khorosani R. Gastroenteropancreatic neuroendocrine tumors: impact of consistent contrast agent selection on radiologists' confidence in hepatic lesion assessment on restarding MRIs. Abdominal Radiology. 2018; 6 (43): 1386-92.

9. Eremina OE, Semenova AA, Sergeeva EA, Brazhe NA, Maksimov GV, Shekhovtsova TN, Goodilin EA, Veselova IA, Surface enhanced Raman spectroscopy in modern chemical analysis: achievements and prospects. Russ Chem Rev. 2018; 87 (8): 741-70, DOI: doi. org/10.1070/RCR4804.

10. Vatsadze SZ, Eremina OE, Veselova IA, Kalmykov SN, Nenajdenko VG. $18 \mathrm{~F}$-Labelled catecholamine type radiopharmaceuticals in the diagnosis of neurodegenerative diseases and neuroendocrine tumours: approaches to synthesis and development prospects. Russ Chem Rev. 2018; 87 (4): 350-73, DOl: doi.org/10.1070/ RCR4752/

11. Veselova IA, Sergeeva EA, Makedonskaya MI, Eremina OE, Kalmykov SN, Shekhovtsova TN. Metodi opredeleniya markerov neyromediatornogo obmena $v$ celyah klinicheskoy diagnostiki. Russian Journal of Analytical chemistry. 2016; 71 (12): 1235-49.

12. Kneipp K, Wang Y, Kneipp H, Perelman LT, Itzkan I, Dasari RR et al. Single molecule detection using surface-enhanced Raman scattering (SERS). Phys Rev Lett. 1997; (78): 1667-70.

13. Olenin AY, Lisichkin GV. Metal nanoparticles in condensed media: preparation and the bulk and surface structural dynamics. Russ Chem Rev. 2011; (80): 605-35.

14. Cialla D, März A, Böhme R, Theil F, Weber K, Schmitt M et al. Surface-enhanced Raman spectroscopy (SERS): Progress and trends. Anal Bioanal Chem. 2012; (403): 27-54.

15. Laing S, Gracie K, Faulds K. Multiplex in vitro detection using SERS. Chem Soc Rev. 2016; (45): 1901-18.

16. Semenova AA, Goodilin EA, Brazhe NA, Ivanov VK, Baranchikov AE, Lebedev VA et al. Planar SERS nanostructures with stochastic silver ring morpholgy for biosensor chips. J Mater Chem. 2012; (22): 24530-44.

17. Semenova AA, Brazhe NA, Parshina EY, Sarycheva AS, Maksimov GV, Goodilin EA. A new route for SERS analysis of intact erythrocytes using polydisperse silver nanoplatelets on biocompatible scaffolds. RSC Adv. 2016; (6): 85156-63.

18. Brazhe NA, Evlyukhin AB, Goodilin EA, Semenova AA, Novikov SM, Bozhevolnyi SI et al. Probing cytochrome $\mathrm{c}$ in living mitochondria with surface-enhanced Raman spectroscopy. Sci Rep. 2015; (5): 13793(1)-13793(13)
19. Durmanov NN, Guliev RR, Eremenko AV, Boginskaya IA, Ryzhikov IA, Trifonova EA et al. Non-labeled selective virus detection with novel SERS-active porous silver nanofilms fabricated by Electron Beam Physical Vapor Deposition. Sens Actuators B. 2018; (257): 37-47.

20. Nechaeva N, Prokopkina T, Makhaeva G, Rudakova E, Boltneva N, Dishovsky et al. Quantitative butyrylcholinesterase activity detection by surface-enhanced Raman spectroscopy. Sens Actuators B. 2018; (259): 75-82.

21. Kneipp J, Kneipp H, Wittig B, Kneipp K. One- and two-photon excited optical ph probing for cells using surface-enhanced Raman and hyper-Raman nanosensors. Nano Lett. 2007; (7): 2819-23.

22. Drescher D, Kneipp J. Nanomaterials in complex biological systems: insights from Raman spectroscopy. Chem Soc Rev. 2012; (41): 5780-99.

23. Wood BR, Caspers P, Puppels GJ, Pandiancherri S, McNaughton D. Resonance Raman spectroscopy of red blood cells using nearinfrared laser excitation. Anal Bioanal Chem. 2007; (387): 1691-703.

24. Brazhe NA, Parshina EY, Khabatova W, Semenova AA, Brazhe AR, Yusipovich Al et al. Tuning SERS for living erythrocytes: Focus on nanoparticle size and plasmon resonance position. J Raman Spectrosc. 2013; (44): 686-94.

25. Semenova AA, Brazhe NA, Parshina EY, Ivanov VK, Maksimov GV, Goodilin EA. Aqueous diaminsilver hydroxide as a precursor of pure silver nanoparticles for SERS probing of living erythrocytes. Plasmonics. 2013; (9): 227-35.

26. Jarvis RM, Goodacre R. Discrimination of bacteria using surfaceenhanced Raman spectroscopy. Anal Chem. 2004; (76): 40-7.

27. Wang P, Pang S, Chen J, McLandsborough L, Nugen SR, Fan M et al. Label-free mapping of single bacterial cells using surfaceenhanced Raman spectroscopy. Analyst. 2016; (141): 1356-62.

28. Granger JH, Schlotter NE, Crawford AC, Porter MD. Prospects for point-of-care pathogen diagnostics using surface-enhanced Raman scattering (SERS). Chem Soc Rev. 2016; (45): 3865-82.

29. Hoang V, Tripp RA, Rota P, Dluhy RA. Identification of individual genotypes of measles virus using surface enhanced Raman spectroscopy. Analyst. 2010; (135): 3103-9.

30. Luo S-C, Sivashanmugan K, Liao J-D, Yao C-K, Peng H-C. Nanofabricated SERS-active substrates for single-molecule to virus detection in vitro: A review. Biosens Bioelectron. 2014; (61): 232-40.

31. El-Said WA, Kim SU, Choi J-W. Monitoring in vitro neural stem cell differentiation based on surface-enhanced Raman spectroscopy using a gold nanostar array. J Mater Chem C. 2015; (3): 3848-59.

32. Han J, Qian X, Wu Q, Jha R, Duan J, Yang Z et al. Novel surfaceenhanced Raman scattering-based assays for ultra-sensitive detection of human pluripotent stem cells. Biomaterials. 2016; (105): 66-76.

33. Howes PD, Rana S, Stevens MM. Plasmonic nanomaterials for biodiagnostics. Chem Soc Rev. 2014; (43): 383-8.

34. McAughtrie S, Faulds K, Graham D. Surface enhanced Raman spectroscopy (SERS): potential applications for disease detection and treatment. J Photochem Photobiol C. 2014; (21): 40-53.

35. Puppels GJ, de Mul FFM, Otto C, Greve J, Robert-Nicoud M, Arndt-Jovin DJ et al. Studying single living cells and chromosomes by confocal Raman microspectroscopy. Nature. 1990; (347): 3013.

36. Alvarez-Puebla RA, Liz-Marzán LM. SERS-based diagnosis and biodetection. Small. 2010; (6): 604-10.

37. März A, Mönch B, Rösch P, Kiehntopf M, Henkel T, Popp J. Detection of thiopurine methyltransferase activity in lysed red blood cells by means of lab-on-a-chip surface enhanced Raman spectroscopy (LOC-SERS). Anal Bioanal Chem. 2011; (400): 2755-61.

38. Jahn IJ, Žukovskaja O, Zheng X-S, Weber K, Bocklitz TW, Cialla-May D et al. Surface-enhanced Raman spectroscopy and microfluidic platforms: challenges, solutions and potential applications. Analyst. 2017; (142): 1022-47.

39. Kumar S, Goel P, Singh JP. A facile method for fabrication of buckled PDMS silver nanorod arrays as active 3D SERS cages for 
bacterial sensing. Sens Actuators B. 2017; (241): 577-83.

40. Polavarapu L, Perez-Juste J, Xu Q, Liz-Marzán LM. Optical sensing of biological, chemical and ionic species through aggregation of plasmonic nanoparticles. J Mater Chem C. 2014; (2): 7460-76.

41. Dhillon A, Nair M, Kumar D. Analytical methods for sensing of health-hazardous arsenic from biotic and abiotic natural resources. Anal Methods. 2015; (7): 10088-108.

42. Xiao L, Zhang M, Liu Z, Bian W, Zhang X, Zhan J. Hydrophobic silver nanowire membrane for swabbing extraction and in situ SERS detection of polycyclic aromatic hydrocarbons on toys. Anal Methods. 2017; (9): 1816-24.

43. Fleischmann M, Hendra PJ, McQuillan AJ. Raman spectra of pyridine adsorbed at a silver electrode. Chem Phys Lett. 1974; (26): 163-6.

44. Wachsmann-Hogiu S, Weeks T, Huser T. Chemical analysis in vivo and in vitro by Raman spectroscopy - From single cells to humans. Curr Opin Biotechnol. 2009; (20): 63-73.

45. Yazdi SH, White IM. A nanoporous optofluidic microsystem for highly sensitive and repeatable surface enhanced Raman spectroscopy detection. Biomicrofluidics. 2012; (6): 14105-59.

46. Sharma VK, Yngard RA, Lin Y. Green synthesis and their antimicrobial activities. Adv Colloid Interface Sci. 2009; (145): 83-96.

47. Sun Y. Shape-controlled synthesis of gold and silver nanoparticles. Science. 2002; (298): 2176-9.

48. Guerrero-Martínez A, Barbosa S, Pastoriza-Santos I, Liz-Marzán LM. Nanostars shine bright for you: colloidal synthesis, properties and applications of branched metallic nanoparticles. Curr Opin Colloid Interface Sci. 2011; (16): 118-27.

49. Lim B, Xia Y. Metal nanocrystals with highly branched morphologies. Angew Chem Int Ed. 2011; (50): 76-85.

50. Pietrobon B, Kitaev V. Photochemical synthesis of monodisperse size-controlled silver decahedral nanoparticles and their remarkable optical properties. Chem Mater. 2008; (20): 5186-90.

51. Phan-Quang GC, Lee HK, Phang IY, Ling XY. Plasmonic colloidosomes as three-dimensional SERS platforms with enhanced surface area for multiphase sub-microliter toxin sensing. Angew Chem Int Ed. 2015; (54): 9691-5.

52. Tien D-C, Liao C-Y, Huang J-C, Tseng K-H, Lung J-K, Tsung T-T et al. Novel technique for preparing a nano-silver water suspension by the arc-discharge method. Rev Adv Mater Sci. 2008; (18): 750-6.

53. Gongalsky MB, Osminkina LA, Pereira A, Manankov AA, Fedorenko AA, Vasiliev AN et al. Laser-synthesized oxidepassivated bright Si quantum dots for bioimaging. Sci Rep. 2016; (6): 24732(1)-24732(8)

54. Nadagouda MN, Varma RS. Green synthesis of silver and palladium nanoparticles at room temperature using coffee and tea extract. Green Chem. 2008; (10): 859-62.

55. Moulton MC, Braydich-Stolle LK, Nadagouda MN, Kunzelman S, Hussain SM, Varma RS. Synthesis, characterization and biocompatibility of "green" synthesized silver nanoparticles using tea polyphenols. Nanoscale. 2010; (2): 763-70.

56. Hwang $\mathrm{H}$, Chon $\mathrm{H}$, Choo J, Park JK. Optoelectrofluidic sandwich immunoassays for detection of human tumor marker using surface-enhanced Raman scattering. Analyt Chem. 2010; (82): 7603-10.

57. Li J-M, Ma W-F, Wei C, Guo J, Hu J, Wang C-C. Poly(styreneco-acrylic acid) core and silver nanoparticle/silica shell composite microspheres as high performance surface-enhanced Raman spectroscopy (SERS) substrate and molecular barcode label. $J$ Mater Chem. 2011; (21): 5992-98.

58. Chen J-W, Lei Y, Liu X-J, Jiang J-H, Shen G-L, Yu R-Q. Immunoassay using surface-enhanced Raman scattering based on aggregation of reporter-labeled immunogold nanoparticles. Anal Bioanal Chem. 2008; (392): 187-93.

59. Ma K, Yuen JM, Shah NC, Walsh JT, Glucksberg MR, Van Duyne RP. In Vivo, transcutaneous glucose sensing using surface-enhanced spatially offset Raman spectroscopy: multiple rats, improved hypoglycemic accuracy, low incident power, and continuous monitoring for greater than 17 days. Anal Chem. 2011; (83): 9146-52.

60. Pînzaru SC, Andronie LM, Domsa I, Cozar O, Astilean S. Bridging biomolecules with nanoparticles: surface-enhanced Raman scattering from colon carcinoma and normal tissue. J Raman Spectrosc. 2008; (39): 331-4

61. Wang X, Qian X, Beitler JJ, Chen ZG, Khuri FR, Lewis MM et al. Detection of circulating tumor cells in human peripheral blood using surface-enhanced Raman scattering nanoparticles. Cancer Res. 2011; (71): 1526-32.

62. Thomson PIT, Camus VL, Hu Y, Campbell CJ. Series of quinonecontaining nanosensors for biologically relevant redox potential determination by surface-enhanced Raman spectroscopy. Anal Chem. 2015; 87 (9): 4719-35.

63. Qu L-L, Li D-W, Qin L-X, Mu J, Fossey JS, Long Y-T. Selective and sensitive detection of intracellular O2(•-) using Au NPs/cytochrome $c$ as SERS nanosensors. Anal Chem. 2013; 85 (20): 9549-55.

64. Sivanesan A, Witkowska E, Adamkiewicz W, Dziewit Ł, Kamińska A Waluk J. Nanostructured silver-gold bimetallic SERS substrates for selective identification of bacteria in human blood. Analyst. 2013; 139 (5): 1037-43.

65. Vitol EA, Orynbayeva Z, Bouchard MJ, Azizkhan-Clifford J, Friedman G, Gogotsi Y. In situ intracellular spectroscopy with surface enhanced Raman spectroscopy (SERS)-enabled nanopipettes. ACS Nano. 2009; 3 (11): 3529-36.

66. Vitol EA, Brailoiu E, Orynbayeva Z, Dun NJ, Friedman G, Gogotsi Y. Surface-enhanced Raman spectroscopy as a tool for detecting $\mathrm{Ca} 2+$ mobilizing second messengers in cell extracts. Anal Chem. 2010; 8 (16): 6770-4.

67. Zhang Q, Lu X, Tang P, Zhang D, Tian J, Zhong L. Gold nanoparticle (AuNP)-based surface-enhanced Raman scattering (SERS) probe of leukemic lymphocytes. Plasmonics. 2016; (11): 1361-8.

68. Berezhna S, Wohlrab H, Champion PM. Resonance Raman investigations of cytochrome $\mathrm{c}$ conformational change upon interaction with the membranes of intact and $\mathrm{Ca} 2+-$-exposed mitochondria. Biochemistry. 2003; (42): 6149-58.

69. Pankratova MS, Baizhumanov AA, Yusipovich Al, Faassen M, Shiryaeva TYu, Peterkova VA et al. Imbalance in the blood antioxidant systemin growth hormone-deficient children before and after 1 year of recombinant growth hormone therapy. Peer $\mathrm{J}$. 2015; (3): e1055(1)-e1055(12).

70. Brazhe NA, Baizhumanov AA, Parshina EYu, Yusipovich Al, Akhalaya MYa, Yarlykova YuV et al. Studies of the blood antioxidant system and oxygen-transporting properties of human erythrocytes during 105-day isolation. Human physiology. 2014; (40): 804-9.

71. Rodan LH, Gibson KM, Pearl PL. Clinical Use of CSF Neurotransmitters J Pediatr Neurol. 2015; 53 (4): 277-86.

72. Eisenhofer G, Kopin IJ, Goldstein DS. Catecholamine metabolism: a contemporary view with implications for physiology and medicine. Pharmacol Rev. 2004; 56 (3): 331-49.

73. Goldstein DS, Kopin IJ, Sharabi Y. Catecholamine autotoxicity. Implications for pharmacology and therapeutics of Parkinson disease and related disorders. Pharmacol Ther. 2014; 144 (3): 268-82.

74. Postuma RB, Gagnon JF, Vendette M, Montplaisir JY. Markers of neurodegeneration in idiopathic rapid eye movement sleep behaviour disorder and Parkinson's disease. Brain. 2009; 132 (12): 3298-307.

75. Subramaniam R. Pheochromocytoma - current concepts in diagnosis and management. Trends Anaesth Crit Care. 2011; 1 (2): 104-10.

76. Yangong $\mathrm{H}$, Shi $\mathrm{C}$, Shahbaz M, Zhengchuan N, Wang J, Liang B et al. Diagnosis and treatment experience of rectal carcinoid (a report of 312 cases). Int J Surg. 2014; 12 (5): 408-11.

77. Sadilkova K, Dugaw K, Benjamin D, Jack RM. Analysis of vanillylmandelic acid and homovanillic acid by UPLC-MS/MS in serum for diagnostic testing for neuroblastoma. Clin Chim Acta. 2013; (424): 253-7.

78. Rodriguez MC, Rubianes MD, Rivas GA. Highly selective determination of dopamine in the presence of ascorbic acid and serotonin at glassy carbon electrodes modified with carbon nanotubes dispersed in polyethylenimine. J Nanosci Nanotechnol. 2008; 8 (11): 6003-9.

79. Mazloum-Ardakani M, Khoshroo A. High performance electrochemical sensor based on fullerene-functionalized carbon nanotubes/ionic liquid: Determination of some catecholamines. Electrochem Comm. 2014; (42): 9-12. 
80. Rezaei B, Boroujeni MK, Ensafi AA. Fabrication of DNA o-phenylenediamine, and gold nanoparticle bioimprinted polymer electrochemical sensor for the determination of dopamine. Biosens. Bioelectron. 2015; (66): 490-6.

81. Gao N, Xu Z, Wang F, Dong SJ. Sensitive biomimetic sensor based on molecular imprinting at functionalized indium tin oxide electrodes. Electroanalisis. 2007; (19): 1655-60.

82. Poliakov AE, Dumshakova AV, Muginova SV, Shekhovtsova TN. A peroxidase-based method for the determination of dopamine, adrenaline, and $\alpha$-methyldopa in the presence of thyroid hormones in pharmaceutical forms. Talanta. 2011; 84 (3): 710-6.

83. Huang H, Gao Y, Shi F, Wang G, Shah SM, Su X. Determination of catecholamine in human serum by a fluorescent quenching method based on a water-soluble fluorescent conjugated polymerenzyme hybrid system. Analyst. 2012; 137 (6): 1481-6.

84. Liu CH, Yu CJ, Tseng WL. Fluorescence assay of catecholamines based on the inhibition of peroxidase-like activity of magnetite nanoparticles. Anal Chim Acta. 2012; (745): 143-8.

85. Schulze HG, Blades MW, Bree AV, Gorzalka BB, Greek LS, Turner RFB. Characteristics of backpropagation neural networks employed in the identification of neurotransmitter Raman spectra. Appl Spectrosc. 1994; (48): 50-7.

86. Sharma B, Frontiera RR, Henry Al, Ringe E, Van Duyne RP. SERS: Materials, applications, and the future. Mater Today. 2012; (15): 16-25.

\section{Литература}

1. Semkina A, Abakumov M, Grinenko N, Abakumov A, Skorikov A, Mironova $E$ et al. Core-shell-corona doxorubicin-loaded superparamagnetic Fe3O4 nanoparticles for cancer theranostics. Colloids Surf B Biointerfaces. 2015; (136): 1073-80.

2. Chekhonin VP, Baklaushev VP, Yusubalieva GM, Belorusova AE, Gulyaev MV, Tsitrin EB et al. Targeted delivery of liposomal nanocontainers to the peritumoral zone of glioma by means of monoclonal antibodies against GFAP and the extracellular loop of Cx43. Nanomedicine. 2012; 8 (1): 63-70.

3. Nukolova NV, Aleksashkin AD, Abakumova TO, Morozova AY, Gubskiy IL, Kirzhanova EA et al. Multilayer polyion complex nanoformulations of superoxide dismutase 1 for acute spinal cord injury. J Control Release. 2018; (270): 226-36.

4. Ковалева Е. В., Синюкова Г. Т., Данзанова Т. Ю., Лепэдату П. И., Гудилина Е. А., Возможности УЗИ с применением контрастного усиления в диагностике метастазов в печени у больных колоректальным раком. Колопроктология. 2018; 1 (63): 36-42.

5. Бердников С. Н., Шолохов В. Н., Синюкова Г. Т., Гудилина Е. А., Абгарян М. Г., Калинин А. Е. и др. Дифференциальная диагностика очаговых гиперэхогенных образований в печени Колопроктология. 2017; 2 (60): 19-25.

6. Nirmala D. Review: Medical image contrast enhancement techniques, Research Journal of Pharmaceutical Biological and Chemical Sciences. 2015; 6 (3): 321-9.

7. Chen F, Hableel G, Zhao ER, Jokerst JV. Multifunctional nanomedicine with silica: Role of silica in nanoparticles for theranostic, imaging and drug monitoring. J Colloid and Interface Science. 2018; (521): 261-79

8. Balthazar $\mathrm{P}$, Shinagare $\mathrm{AB}$, Tirumani $\mathrm{SH}$, Jagannathan JP, Ramaiya NH, Khorosani R. Gastroenteropancreatic neuroendocrine tumors: impact of consistent contrast agent selection on radiologists' confidence in hepatic lesion assessment on restarding MRIs. Abdominal Radiology. 2018; 6 (43): 1386-92.

9. Еремина О. Е., Семенова А. А., Сергеева Е. А., Браже Н. А., Максимов Г. В., Шеховцова Т. Н. и др. Спектроскопия гигантского комбинационного рассеяния в современном химическом анализе: достижения и перспективы использования. Успехи химии. 2018; 87 (8): 741-70.

10. Вацадзе С. З., Еремина О. Е., Веселова И. А., Калмыков С. Н., Ненайденко В. Г., Радиофармпрепараты группы катехоламинов, меченные 18F, в диагностике нейродегенеративных заболеваний и нейроэндокринных опухолей: подходы $\mathrm{k}$ синтезу и перспективы развития. Успехи Химии. 2018; 87 (4): 350-73.
87. Lim JW, Kang IJ. Fabrication of chitosan-gold nanocomposites combined with optical fiber as SERS substrates to detect dopamine molecules. Bull Korean Chem Soc. 2014; (35): 25-9.

88. Lim JW, Kang IJ. Chitosan-gold nano composite for dopamine analysis using Raman scattering. Bull Korean Chem Soc. 2013; (34): 237-42.

89. Tang L, Li S, Han F, Liu L, Xu L, Ma W et al. SERS-active Au@ Ag nanorod dimers for ultrasensitive dopamine detection. Biosens Bioelectron. 2015; (71): 7-12.

90. Lee NS, Hsieh YZ, Paisley RF, Morris MD. Surface enhanced Raman spectroscopy of the catecholamine neurotransmitters and related compounds. Anal Chem. 1998; (60): 442-6.

91. Kneipp K, Wang Y, Dasari RR, Feld MS. Near-infrared surfaceenhanced Raman scattering (NIR-SERS) of neurotransmitters in colloidal silver solutions. Spectrochim Acta. 1995; (51A): 481-7.

92. Volkan M, Stokes DL, Vo-Dinh T. Surface-Enhanced Raman of dopamine and neurotransmitters using sol-gel substrates and polymer-coated fiber-optic probes. Appl Spectrosc. 2000; 54 (12): 1842-8.

93. Barreto WJ, Barreto SRG, Ando RA, Santos PS, DiMauro E, Jorge T. Raman, IR, UV-vis and EPR characterization of two copper dioxolene complexes derived from L-DOPA and dopamine. Spectrochim. Acta Part A. 2008; 71 (4): 1419-24.
11. Веселова И. А., Сергеева Е. А., Македонская М. И., Еремина О. Е., Калмыков С. Н., Шеховцова Т. Н., Методы определения маркеров нейромедиаторного обмена в целях клинической диагностики. Журнал аналитической химии. 2016; 71 (12): 1235-49.

12. Kneipp K, Wang Y, Kneipp H, Perelman LT, Itzkan I, Dasari RR et al. Single molecule detection using surface-enhanced Raman scattering (SERS). Phys Rev Lett. 1997; (78): 1667-70.

13. Оленин А. Ю., Лисичкин Г.В.Получение, динамика структуры объема и поверхности металлических наночастиц в конденсированных средах. Успехи химии. 2011; 80: 605-35.

14. Cialla D, März A, Böhme R, Theil F, Weber K, Schmitt M et al. Surface-enhanced Raman spectroscopy (SERS): Progress and trends. Anal Bioanal Chem. 2012; (403): 27-54.

15. Laing S, Gracie K, Faulds K. Multiplex in vitro detection using SERS. Chem Soc Rev. 2016; (45): 1901-18.

16. Semenova AA, Goodilin EA, Brazhe NA, Ivanov VK, Baranchikov AE, Lebedev VA et al. Planar SERS nanostructures with stochastic silver ring morpholgy for biosensor chips. J Mater Chem. 2012; (22): 24530-44

17. Semenova AA, Brazhe NA, Parshina EY, Sarycheva AS, Maksimov GV, Goodilin EA. A new route for SERS analysis of intact erythrocytes using polydisperse silver nanoplatelets on biocompatible scaffolds. RSC Adv. 2016; (6): 85156-63.

18. Brazhe NA, Evlyukhin AB, Goodilin EA, Semenova AA, Novikov SM, Bozhevolnyi SI et al. Probing cytochrome $\mathrm{c}$ in living mitochondria with surface-enhanced Raman spectroscopy. Sci Rep. 2015; (5): 13793(1)-13793(13).

19. Durmanov NN, Guliev RR, Eremenko AV, Boginskaya IA Ryzhikov IA, Trifonova EA et al. Non-labeled selective virus detection with novel SERS-active porous silver nanofilms fabricated by Electron Beam Physical Vapor Deposition. Sens Actuators B. 2018; (257): 37-47.

20. Nechaeva N, Prokopkina T, Makhaeva G, Rudakova E, Boltneva N, Dishovsky et al. Quantitative butyrylcholinesterase activity detection by surface-enhanced Raman spectroscopy. Sens Actuators B. 2018; (259): 75-82.

21. Kneipp J, Kneipp H, Wittig B, Kneipp K. One- and two-photon excited optical ph probing for cells using surface-enhanced Raman and hyper-Raman nanosensors. Nano Lett. 2007; (7): 2819-23.

22. Drescher D, Kneipp J. Nanomaterials in complex biological systems: insights from Raman spectroscopy. Chem Soc Rev. 
2012; (41): 5780-99

23. Wood BR, Caspers P, Puppels GJ, Pandiancherri S, McNaughton D. Resonance Raman spectroscopy of red blood cells using nearinfrared laser excitation. Anal Bioanal Chem. 2007; (387): 1691703.

24. Brazhe NA, Parshina EY, Khabatova W, Semenova AA, Brazhe AR, Yusipovich Al et al. Tuning SERS for living erythrocytes: Focus on nanoparticle size and plasmon resonance position. J Raman Spectrosc. 2013; (44): 686-94.

25. Semenova AA, Brazhe NA, Parshina EY, Ivanov VK, Maksimov GV, Goodilin EA. Aqueous diaminsilver hydroxide as a precursor of pure silver nanoparticles for SERS probing of living erythrocytes. Plasmonics. 2013; (9): 227-35.

26. Jarvis RM, Goodacre R. Discrimination of bacteria using surfaceenhanced Raman spectroscopy. Anal Chem. 2004; (76): 40-7.

27. Wang P, Pang S, Chen J, McLandsborough L, Nugen SR, Fan M et al. Label-free mapping of single bacterial cells using surfaceenhanced Raman spectroscopy. Analyst. 2016; (141): 1356-62.

28. Granger JH, Schlotter NE, Crawford AC, Porter MD. Prospects for point-of-care pathogen diagnostics using surface-enhanced Raman scattering (SERS). Chem Soc Rev. 2016; (45): 3865-82.

29. Hoang V, Tripp RA, Rota P, Dluhy RA. Identification of individual genotypes of measles virus using surface enhanced Raman spectroscopy. Analyst. 2010; (135): 3103-9.

30. Luo S-C, Sivashanmugan K, Liao J-D, Yao C-K, Peng H-C. Nanofabricated SERS-active substrates for single-molecule to virus detection in vitro: A review. Biosens Bioelectron. 2014; (61): 232-40.

31. El-Said WA, Kim SU, Choi J-W. Monitoring in vitro neural stem cell differentiation based on surface-enhanced Raman spectroscopy using a gold nanostar array. J Mater Chem C. 2015; (3): 3848-59.

32. Han J, Qian X, Wu Q, Jha R, Duan J, Yang Z et al. Novel surfaceenhanced Raman scattering-based assays for ultra-sensitive detection of human pluripotent stem cells. Biomaterials. 2016; (105): 66-76.

33. Howes PD, Rana S, Stevens MM. Plasmonic nanomaterials for biodiagnostics. Chem Soc Rev. 2014; (43): 383-8.

34. McAughtrie S, Faulds K, Graham D. Surface enhanced Raman spectroscopy (SERS): potential applications for disease detection and treatment. J Photochem Photobiol C. 2014; (21): 40-53.

35. Puppels GJ, de Mul FFM, Otto C, Greve J, Robert-Nicoud M, Arndt-Jovin DJ et al. Studying single living cells and chromosomes by confocal Raman microspectroscopy. Nature. 1990; (347): 301-3.

36. Alvarez-Puebla RA, Liz-Marzán LM. SERS-based diagnosis and biodetection. Small. 2010; (6): 604-10.

37. März A, Mönch B, Rösch P, Kiehntopf M, Henkel T, Popp J. Detection of thiopurine methyltransferase activity in lysed red blood cells by means of lab-on-a-chip surface enhanced Raman spectroscopy (LOC-SERS). Anal Bioanal Chem. 2011; (400): 2755-61.

38. Jahn IJ, Žukovskaja O, Zheng X-S, Weber K, Bocklitz TW, Cialla-May D et al. Surface-enhanced Raman spectroscopy and microfluidic platforms: challenges, solutions and potential applications. Analyst. 2017; (142): 1022-47.

39. Kumar S, Goel P, Singh JP. A facile method for fabrication of buckled PDMS silver nanorod arrays as active 3D SERS cages for bacterial sensing. Sens Actuators B. 2017; (241): 577-83.

40. Polavarapu L, Perez-Juste J, Xu Q, Liz-Marzán LM. Optical sensing of biological, chemical and ionic species through aggregation of plasmonic nanoparticles. J Mater Chem C. 2014; (2): 7460-76.

41. Dhillon A, Nair M, Kumar D. Analytical methods for sensing of health-hazardous arsenic from biotic and abiotic natural resources. Anal Methods. 2015; (7): 10088-108.

42. Xiao L, Zhang M, Liu Z, Bian W, Zhang X, Zhan J. Hydrophobic silver nanowire membrane for swabbing extraction and in situ SERS detection of polycyclic aromatic hydrocarbons on toys. Ana Methods. 2017; (9): 1816-24.

43. Fleischmann M, Hendra PJ, McQuillan AJ. Raman spectra of pyridine adsorbed at a silver electrode. Chem Phys Lett. 1974; (26): 163-6.

44. Wachsmann-Hogiu S, Weeks T, Huser T. Chemical analysis in vivo and in vitro by Raman spectroscopy - From single cells to humans. Curr Opin Biotechnol. 2009; (20): 63-73.
45. Yazdi SH, White IM. A nanoporous optofluidic microsystem for highly sensitive and repeatable surface enhanced Raman spectroscopy detection. Biomicrofluidics. 2012; (6): 14105-59.

46. Sharma VK, Yngard RA, Lin Y. Green synthesis and their antimicrobial activities. Adv Colloid Interface Sci. 2009; (145): 83-96.

47. Sun Y. Shape-controlled synthesis of gold and silver nanoparticles. Science. 2002; (298): 2176-9.

48. Guerrero-Martínez A, Barbosa S, Pastoriza-Santos I, Liz-Marzán LM. Nanostars shine bright for you: colloidal synthesis, properties and applications of branched metallic nanoparticles. Curr Opin Colloid Interface Sci. 2011; (16): 118-27.

49. Lim B, Xia Y. Metal nanocrystals with highly branched morphologies. Angew Chem Int Ed. 2011; (50): 76-85.

50. Pietrobon B, Kitaev V. Photochemical synthesis of monodisperse size-controlled silver decahedral nanoparticles and their remarkable optical properties. Chem Mater. 2008; (20): 5186-90.

51. Phan-Quang GC, Lee HK, Phang IY, Ling XY. Plasmonic colloidosomes as three-dimensional SERS platforms with enhanced surface area for multiphase sub-microliter toxin sensing. Angew Chem Int Ed. 2015; (54): 9691-5.

52. Tien D-C, Liao C-Y, Huang J-C, Tseng K-H, Lung J-K, Tsung T-T et al. Novel technique for preparing a nano-silver water suspension by the arc-discharge method. Rev Adv Mater Sci. 2008; (18): 750-6.

53. Gongalsky MB, Osminkina LA, Pereira A, Manankov AA Fedorenko AA, Vasiliev AN et al. Laser-synthesized oxidepassivated bright Si quantum dots for bioimaging. Sci Rep. 2016; (6): 24732(1)-24732(8).

54. Nadagouda MN, Varma RS. Green synthesis of silver and palladium nanoparticles at room temperature using coffee and tea extract. Green Chem. 2008; (10): 859-62.

55. Moulton MC, Braydich-Stolle LK, Nadagouda MN, Kunzelman S, Hussain SM, Varma RS. Synthesis, characterization and biocompatibility of "green" synthesized silver nanoparticles using tea polyphenols. Nanoscale. 2010; (2): 763-70.

56. Hwang $\mathrm{H}$, Chon $\mathrm{H}$, Choo J, Park JK. Optoelectrofluidic sandwich immunoassays for detection of human tumor marker using surface-enhanced Raman scattering. Analyt Chem. 2010; (82): 7603-10.

57. Li J-M, Ma W-F, Wei C, Guo J, Hu J, Wang C-C. Poly(styreneco-acrylic acid) core and silver nanoparticle/silica shell composite microspheres as high performance surface-enhanced Raman spectroscopy (SERS) substrate and molecular barcode label. J Mater Chem. 2011; (21): 5992-98.

58. Chen J-W, Lei Y, Liu X-J, Jiang J-H, Shen G-L, Yu R-Q. Immunoassay using surface-enhanced Raman scattering based on aggregation of reporter-labeled immunogold nanoparticles. Anal Bioanal Chem. 2008; (392): 187-93.

59. Ma K, Yuen JM, Shah NC, Walsh JT, Glucksberg MR, Van Duyne RP In Vivo, transcutaneous glucose sensing using surface-enhanced spatially offset Raman spectroscopy: multiple rats, improved hypoglycemic accuracy, low incident power, and continuous monitoring for greater than 17 days. Anal Chem. 2011; (83): 9146-52.

60. Pînzaru SC, Andronie LM, Domsa I, Cozar O, Astilean S. Bridging biomolecules with nanoparticles: surface-enhanced Raman scattering from colon carcinoma and normal tissue. J Raman Spectrosc. 2008; (39): 331-4.

61. Wang X, Qian X, Beitler JJ, Chen ZG, Khuri FR, Lewis MM et al. Detection of circulating tumor cells in human peripheral blood using surface-enhanced Raman scattering nanoparticles. Cancer Res. 2011; (71): 1526-32.

62. Thomson PIT, Camus VL, Hu Y, Campbell CJ. Series of quinonecontaining nanosensors for biologically relevant redox potential determination by surface-enhanced Raman spectroscopy. Anal Chem. 2015; 87 (9): 4719-35.

63. Qu L-L, Li D-W, Qin L-X, Mu J, Fossey JS, Long Y-T. Selective and sensitive detection of intracellular O2(•-) using Au NPs/cytochrome $c$ as SERS nanosensors. Anal Chem. 2013; 85 (20): 9549-55.

64. Sivanesan A, Witkowska E, Adamkiewicz W, Dziewit Ł, Kamińska A, Waluk J. Nanostructured silver-gold bimetallic SERS substrates for selective identification of bacteria in human blood. Analyst. 2013; 139 (5): 1037-43. 
65. Vitol EA, Orynbayeva Z, Bouchard MJ, Azizkhan-Clifford J Friedman G, Gogotsi Y. In situ intracellular spectroscopy with surface enhanced Raman spectroscopy (SERS)-enabled nanopipettes. ACS Nano. 2009; 3 (11): 3529-36.

66. Vitol EA, Brailoiu E, Orynbayeva Z, Dun NJ, Friedman G, Gogotsi Y. Surface-enhanced Raman spectroscopy as a tool for detecting $\mathrm{Ca} 2+$ mobilizing second messengers in cell extracts. Anal Chem. 2010; 8 (16): 6770-4.

67. Zhang Q, LuX, Tang P, Zhang D, Tian J, Zhong L. Gold nanoparticle (AuNP)-based surface-enhanced Raman scattering (SERS) probe of leukemic lymphocytes. Plasmonics. 2016; (11): 1361-8.

68. Berezhna S, Wohlrab H, Champion PM. Resonance Raman investigations of cytochrome c conformational change upon interaction with the membranes of intact and $\mathrm{Ca} 2+$-exposed mitochondria. Biochemistry. 2003; (42): 6149-58.

69. Pankratova MS, Baizhumanov AA, Yusipovich Al, Faassen M, Shiryaeva TYu, Peterkova VA et al. Imbalance in the blood antioxidant systemin growth hormone-deficient children before and after 1 year of recombinant growth hormone therapy. Peer $J$ 2015; (3): e1055(1)-e1055(12)

70. Brazhe NA, Baizhumanov AA, Parshina EYu, Yusipovich Al, Akhalaya MYa, Yarlykova YuV et al. Studies of the blood antioxidan system and oxygen-transporting properties of human erythrocytes during 105-day isolation. Human physiology. 2014; (40): 804-9.

71. Rodan LH, Gibson KM, Pearl PL. Clinical Use of CSF Neurotransmitters J Pediatr Neurol. 2015; 53 (4): 277-86.

72. Eisenhofer G, Kopin IJ, Goldstein DS. Catecholamine metabolism: a contemporary view with implications for physiology and medicine. Pharmacol Rev. 2004; 56 (3): 331-49.

73. Goldstein DS, Kopin IJ, Sharabi Y. Catecholamine autotoxicity. Implications for pharmacology and therapeutics of Parkinson disease and related disorders. Pharmacol Ther. 2014; 144 (3) 268-82.

74. Postuma RB, Gagnon JF, Vendette M, Montplaisir JY. Markers of neurodegeneration in idiopathic rapid eye movement sleep behaviour disorder and Parkinson's disease. Brain. 2009; 132 (12): 3298-307.

75. Subramaniam R. Pheochromocytoma - current concepts in diagnosis and management. Trends Anaesth Crit Care. 2011; 1 (2): 104-10.

76. Yangong H, Shi C, Shahbaz M, Zhengchuan N, Wang J, Liang B et al. Diagnosis and treatment experience of rectal carcinoid (a report of 312 cases). Int J Surg. 2014; 12 (5): 408-11.

77. Sadilkova K, Dugaw K, Benjamin D, Jack RM. Analysis of vanillylmandelic acid and homovanillic acid by UPLC-MS/MS in serum for diagnostic testing for neuroblastoma. Clin Chim Acta. 2013; (424): 253-7.

78. Rodriguez MC, Rubianes MD, Rivas GA. Highly selective determination of dopamine in the presence of ascorbic acid and serotonin at glassy carbon electrodes modified with carbon nanotubes dispersed in polyethylenimine. J Nanosci Nanotechnol. 2008; 8 (11): 6003-9.
79. Mazloum-Ardakani M, Khoshroo A. High performance electrochemical sensor based on fullerene-functionalized carbon nanotubes/ionic liquid: Determination of some catecholamines. Electrochem Comm. 2014; (42): 9-12.

80. Rezaei B, Boroujeni MK, Ensafi AA. Fabrication of DNA, o-phenylenediamine, and gold nanoparticle bioimprinted polymer electrochemical sensor for the determination of dopamine. Biosens Bioelectron. 2015; (66): 490-6.

81. Gao N, Xu Z, Wang F, Dong SJ. Sensitive biomimetic sensor based on molecular imprinting at functionalized indium tin oxide electrodes. Electroanalisis. 2007; (19): 1655-60.

82. Poliakov AE, Dumshakova AV, Muginova SV, Shekhovtsova TN A peroxidase-based method for the determination of dopamine, adrenaline, and $\alpha$-methyldopa in the presence of thyroid hormones in pharmaceutical forms. Talanta. 2011; 84 (3): 710-6.

83. Huang $H$, Gao Y, Shi F, Wang G, Shah SM, Su X. Determination of catecholamine in human serum by a fluorescent quenching method based on a water-soluble fluorescent conjugated polymerenzyme hybrid system. Analyst. 2012; 137 (6): 1481-6.

84. Liu CH, Yu CJ, Tseng WL. Fluorescence assay of catecholamines based on the inhibition of peroxidase-like activity of magnetite nanoparticles. Anal Chim Acta. 2012; (745): 143-8.

85. Schulze HG, Blades MW, Bree AV, Gorzalka BB, Greek LS, Turner RFB. Characteristics of backpropagation neural networks employed in the identification of neurotransmitter Raman spectra. Appl Spectrosc. 1994; (48): 50-7.

86. Sharma B, Frontiera RR, Henry Al, Ringe E, Van Duyne RP. SERS: Materials, applications, and the future. Mater Today. 2012; (15): $16-25$.

87. Lim JW, Kang IJ. Fabrication of chitosan-gold nanocomposites combined with optical fiber as SERS substrates to detect dopamine molecules. Bull Korean Chem Soc. 2014; (35): 25-9.

88. Lim JW, Kang IJ. Chitosan-gold nano composite for dopamine analysis using Raman scattering. Bull Korean Chem Soc. 2013; (34): 237-42.

89. Tang L, Li S, Han F, Liu L, Xu L, Ma W et al. SERS-active Au@ Ag nanorod dimers for ultrasensitive dopamine detection. Biosens Bioelectron. 2015; (71): 7-12.

90. Lee NS, Hsieh YZ, Paisley RF, Morris MD. Surface enhanced Raman spectroscopy of the catecholamine neurotransmitters and related compounds. Anal Chem. 1998; (60): 442-6.

91. Kneipp K, Wang Y, Dasari RR, Feld MS. Near-infrared surfaceenhanced Raman scattering (NIR-SERS) of neurotransmitters in colloidal silver solutions. Spectrochim Acta. 1995; (51A): 481-7.

92. Volkan M, Stokes DL, Vo-Dinh T. Surface-Enhanced Raman of dopamine and neurotransmitters using sol-gel substrates and polymer-coated fiber-optic probes. Appl Spectrosc. 2000; 54 (12): $1842-8$

93. Barreto WJ, Barreto SRG, Ando RA, Santos PS, DiMauro E, Jorge T. Raman, IR, UV-vis and EPR characterization of two copper dioxolene complexes derived from L-DOPA and dopamine. Spectrochim. Acta Part A. 2008; 71 (4): 1419-24. 